\title{
Democratic Deliberation in a Multinational Federation
}

\author{
Alain Noël ${ }^{1}$ \\ Département de science politique \\ Université de Montréal
}

Democratic deliberation is an aspiration that, in the most favorable conditions, remains difficult to achieve. In divided or multinational societies, the requirements of democratic theory appear particularly daunting. This article surveys the Canadian debate about democratization and constitutional politics to better understand the significance of democratic deliberation in a concrete case, when principles are evoked in a context where institutions, interests, identities and power also matter. The article proposes to think of deliberation and power politics as closely intertwined and, in fact impossible to separate. Even in the best conditions, multinational deliberations always remain imperfect exercises in practical reason.

Forthcoming in: Critical Review of International Social and Political Philosophy, 2006.

1 alain.noel@umontreal.ca 
The concept of disinterested discussion is undoubtedly relevant and fruitful from a general philosophical standpoint, but it only corresponds in politics to a limit or extreme situation. To try and make it a central category in the analysis of representative government would be treat human beings as if they were angels.

Bernard Manin, Principes du gouvernement représentatif (1996: 255; author's translation)

Democratic deliberation is an aspiration that, in the most favorable conditions, remains difficult to achieve. Ideally, a shared public sphere must exist, and it should make possible a minimum of authentic communication over important collective values and objectives. In divided or multinational societies, these requirements appear particularly daunting. For one thing, there may not be much of a common public sphere, or the public sphere may not offer equal access to all groups and identities. Further, the prevailing standards for acceptable reasons and arguments may not be the same for all (Chambers, 2003: 321-22).

In a recent article, John Dryzek identifies two possible responses to the difficulties posed by divided societies, and proposes a third approach of his own (2005). The first response, which he calls 'agonism,' stresses the irreducible character of differences over identity, and favors engagement and contestation over conciliation, accommodation, and joint decisions. This solution may be respectful of diversity, but it does not appear very conducive to truly shared democratic practices. At the opposite end, a second response, which Dryzek associates with the idea of consociationalism and presents as 'analgesia,' suggests to put aside divisive issues, avoid direct deliberation among constituents, and simply trust elite bargaining. In both instances, the problem of divided societies is solved by avoiding rather than by allowing genuine democratic deliberation over common purposes. Unsatisfied with these responses, Dryzek proposes his own approach, which favors a careful but circumscribed engagement of citizens through 
issue-specific networks, with a focus on concrete needs rather than on more ambitious questions of identity, shared and divergent values, and constitutional arrangements. Canada, the author argues, offers a good example. Or, more precisely, Canada does so when it is not engaged in constitutional debates, which tend to end up in "deadlock, frustration, and failure" (2005: 235). It is indeed after constitutional failures, when it shifts to inaction, that Canada seems to Dryzek "at its best, because individuals on the various sides can then get back to engaging one another in the public sphere where struggle over sovereignty is not at stake. Political leadership can get back to the modus vivendi that makes Canada such a generally successful society. The peace is disturbed only by political philosophers who believe a constitutional solution is required" (2005: 235-36).

Compared to the consociational, 'analgesic' response, Dryzek's solution allows some deliberation, but only in a circumscribed way, over a narrow range of questions. In doing so, it leaves aside the very issues that make divided societies a challenge for democratic theory, and offers a solution that appears both unstable and unsatisfying. Unstable, first, because issues of identity and power-sharing simply cannot be wished away; social actors will make sure they are not forgotten, especially if the identities they promote are denied (Smith, 2003: 157). Unsatisfying, also, because in divided societies unaddressed issues of identity and recognition create or perpetuate injustice. They also tend to poison all democratic deliberations, even over mundane bread and butter issues (Kymlicka, 1998: 146-81).

This being said, Dryzek is on the right track because he poses the problem in a concrete way and seeks responses that allow both the expression of differences and the possibility of genuine deliberation across deep social divides. In this article, I propose to take a few additional steps in this direction, through a more systematic discussion of the recent Canadian experience with deliberation over constitutional issues. For Dryzek, this experience was not positive and only ended in "deadlock, frustration, and failure." Many Canadians think so as well. Even if this were true, as a real-world test for democratic theory this experience would remain in many ways enlightening. For one 
thing, it took place in an old and stable parliamentary democracy, with the best possible conditions for free and open debates. Even secession is, in Canada, a legitimate option. In addition, for a divided society Canada is remarkably peaceful and integrated. The country is an old federation, which has always been multinational, at least implicitly, and it has learned to live with divisions and with complex governance arrangements. The conditions for deliberation, then, were as favorable as they could be, considering the not so harmonious universe of divided societies.

In fact, the Canadian experience is not simply a story of deadlock and failure. The constitutional debates of the last thirty years have also contributed to deepen democracy in the country. In the past, Canadian constitutional politics was seen primarily as a bargaining game among elites. By contrast, contemporary constitutional debates were difficult, but they also opened new possibilities for democratic deliberation. Principles were invoked and debated broadly, and citizens became engaged and they expected to be heard.

In the end, it is true, this deepening of democracy has led to a political impasse. Not only are the constitution and core political institutions now apparently impossible to change, but the very idea of discussing reforms seems unwise, if not foolish. By extension, non-constitutional, 'normal' politics has evolved along similar lines, with elite bargaining and power politics often prevailing over democratic deliberation, or even over collaborative intergovernmental relations (Noël, 2003a). As the number of active participants increased and as the range of issues under consideration broadened, the capacity and willingness to address them in a meaningful way seemed to decrease. In the words of Dryzek, democratic gains with respect to the "franchise" and the "scope" of political debates have apparently been made at the expense of "authenticity," the capacity to engage substantively and genuinely in democratic deliberation (1996: 5). The opening of the constitutional process effectively has led to a closure of the political debate. 
What are we to make of this contradictory evolution? Among Canadian political scientists and philosophers, some see a causal relationship between democratic openness and political closure, and argue that the accommodations or compromises necessary to make a multinational federation work cannot be achieved if citizens are too directly involved. They deplore the democratic evolution of the last decades, and contend that 'analgesia' and the status quo are probably the country's best options. These authors lament, more or less openly, a less deliberative and simpler past. Others see democratization and even 'agonism' as positive and, in any case, unavoidable developments, and display more confidence in the public's capacity to deliberate and reach workable solutions. For them, Canada must move beyond the status quo and can only do so through further democratic deliberations. These authors express a guarded optimism, anchored in a relatively positive view of Canadian civic life. In between are a number of observers of Canadian political life who find appealing the democratic evolution of recent years, but worry about the difficulties such an evolution entails in a multinational federation that has left unaddressed many fundamental issues.

This article surveys more precisely these Canadian debates about democratization and constitutional politics to better understand the significance of democratic deliberation in a concrete case, when principles are evoked in a context where institutions, interests, identities and power also matter. The article's main argument is that Canadian scholars, like most scholars who have studied democratic deliberation, have not paid sufficient attention to the relationships between principles and motives, on the one hand, and interests, identities and power, on the other. Those who trust the deliberative process tend to focus on the power of arguments, whereas the skeptics see only the arguments of power. The more ambivalent majority sees both dimensions, but tends to treat them separately, as if arguments and power each had their moments. In my own work, this is more or less how I have approached the question, some articles being more sensitive to the principles at stake, while others are more focused on power politics. 
This article proposes to think of deliberation and power politics as closely intertwined and, in fact, impossible to separate. Both processes, arguing and bargaining/dominating, take place in situations of conflict, when important ideas and interests are at stake. They evolve concurrently, and one cannot be understood fully without the other. Political conflicts render deliberation difficult, and sometimes prevent it but, in the end, they also make it unavoidable. In this perspective, deliberation on rights and principles always has more importance than what proponents of 'analgesia' would suggest, but it is also more governed by agreed-upon rules and by explicit or implicit compromises than what could be inferred from an 'agonistic' standpoint. A focus on the unavoidable association of power and arguments thus suggests that constitutional debates are in many ways similar to day-to-day politics (Bellamy and Schönlau, 2004). It may not be helpful or even feasible to separate analytically these two aspects of political life, or to seek to limit deliberative processes to specific policy issues.

The first three sections recapitulate the evolution of Canada's political deliberations and survey scholarly interpretations that have celebrated, deplored, or puzzled at the impact of a more open deliberative process on the country's constitutional debates. This survey shows how divided and ambivalent the Canadian scholarly literature is on the question. The fourth section broadens the argument to the general literature on democratic deliberation and proposes a modest but empirically grounded alternative to theories of deliberation that abstract from the real context of politics. The fifth part then returns to early Canadian history to suggest that contemporary difficulties may not be as new as is often assumed and to draw some lessons from past constitutional processes, undoubtedly defined by power as much as by principles. The conclusion discusses briefly the theoretical and political significance of an approach to deliberation that is more attentive to the interplay of arguments, interests, and power, and thus more sensitive to the difficulties but also to the possibilities of democratic deliberation in divided societies. 


\section{Canadian Constitutional Politics: For the Few, For the Many, For Nobody}

Canadian constitutional politics has long been primarily for the few. After the adoption of the British North America Act, in 1867, the country's institutions were, for a long period, relatively stable and immune from popular pressures. There were, of course, significant tensions and crises, associated with the different national, regional and social cleavages (see Simeon and Robinson, 1990: 36-46, 64-73, 92-102, and 13140). Canadian politics, however, remained driven largely by elite bargaining, and progress proved limited and gradual. "This was a period of micro-constitutional politics," writes Peter Russell. "The changes were made one at a time, with a minimum of public involvement" (1993: 64). In Canadian political science, this relative absence of the citizens was conceptualized with references to brokerage politics, cooperative or executive federalism, and consociationalism. Beyond their differences, these approaches all underlined, and sometimes celebrated, the centrality of elite bargaining in the country's political life (see Noël, 1994: 67-68).

Change first came from within Quebec. With the Quiet Revolution, in the early 1960s, Quebec politics changed dramatically. After a long period defined by a defensive and conservative search for autonomy within the Canadian federation - "I'hiver de la survivance" (Dumont, 1993: 324-26) - Quebec nationalism was reconstructed as a proactive and progressive quest for economic and social development, and for national recognition and autonomy. In Canada, reactions were mixed, some forces pushing for accommodation, others for a strong affirmation of a one-nation perspective. At the end of the 1960s, a new equilibrium had been found. Canada would not become, formally at least, a multinational federation; there would be only one nation, defined by two official languages and a multicultural heritage (McRoberts, 1997).

More changes, however, would come from Quebec. Indeed, the Quiet Revolution was primarily an internal transformation of Quebec politics and society. First, the old political culture of patronage and anti-statism, particularly prominent in Quebec, was 
ended through political reforms that reinforced controls over political expenditures and severely limited private contributions to political parties. The 1977 law on the financing of political parties, in particular, was a major democratic breakthrough - with no parallels in Canada or elsewhere in the world - which profoundly transformed Quebec politics (Heintzman, 1983). Second, an active and confident civil society emerged in the period, with the strongest trade unions in North America, a solid and influential women's movement, and a host of other social movements. In turn, this evolution led business interests to organize themselves, thus creating conditions favorable to new forms of tripartite or multipartite collaboration (Noël, 2003b). Third, a new political culture and a strong civil society made it possible to end, through political reforms and collective actions, the linguistic division of labor, and of incomes, that had characterized Quebec society for almost a century (see Noël, 1993; Levine, 1997). This last achievement was truly remarkable, a rare instance of success in ending what Charles Tilly would describe as a "durable inequality" (1998).

The emergence of a more democratic, more organized, and more egalitarian society reinforced Quebec's traditional quest for recognition and autonomy within the Canadian federation, and paved the way for a more ambitious proposition: Quebec sovereignty in association with Canada. This evolution, however, also meant that the objective had to be achieved in a new, more open and democratic way. In 1973, the Parti québécois promised to hold a referendum on sovereignty if it was elected and in 1978, now in power, it adopted Quebec's law on popular consultation. For the first time in Canadian history, the people were considered directly sovereign in constitutional matters. René Lévesque, then Premier of Quebec, noted the unprecedented character of the approach when he launched the Quebec referendum debate in 1980:

We are not used to rendezvous like this referendum, it is the first time in our entire history that such an occasion arises to decide by ourselves, collectively, what we want to be and what direction we want to take for the future (Lévesque, quoted in Resnick, 1990 : 101; author's translation)

As a deliberative exercise, a referendum has many drawbacks. It forces voters into an either/or choice, for a short but dramatic duration, and does not make a genuine 
conversation easy. A referendum can indeed be used to close rather than to open popular debates, as was the case with the 2002 British Columbia "referendum" on native rights. Even when it is not intended, the end result is likely to be closure. This is what happened following the 1992 Charlottetown Accord referendum.

Still, in the context of a country where popular sovereignty had never been affirmed, the 1980 referendum marked a breakthrough and established new political rules, at least in Quebec (Atkinson, 1994: 735). The rest is well-known history. In 1982, Pierre Elliott Trudeau lured René Lévesque by alluding to a possible referendum on the constitution, a possibility that appealed to Lévesque but not to the Premiers who were his allies, and he then proceeded to transform the constitution without the approval of the Quebec government (and without popular consultation). The 1987 Meech Lake and 1992 Charlottetown Accords failed to correct the situation created in 1982, but they opened a broad pan-Canadian debate over the constitution, a debate that engaged citizens in the process as never before, but eventually led to a political impasse.

In 1982, the constitution of the country had been changed with little citizen engagement, except for last-minute concessions in response to the demands of women's groups and Aboriginal peoples. Five years later, in 1987, such an elitist approach no longer seemed possible. The idea that the constitution could be amended by the negotiations of "eleven men" gathered in a closed room had become unacceptable. One cannot avoid noting that this preoccupation for process only emerged when the English-speaking majority felt overwhelmingly dissatisfied with the outcome, and disappeared later on, when more palatable agreements were signed behind closed doors (the 1999 Social Union Framework Agreement is a case in point; see Noël, 2000: 32). Whatever the case, Canadian constitutional politics had now entered a new era, marked by citizen involvement and demands for more open deliberations. The 1992 referendum confirmed the trend, and convinced many in Canada that an era when elites could strike compromises had ended and, with it, the possibility of changing the constitution. 
First debated among the few, Canadian constitutional politics finally had reached the many, but only to end up being for nobody, that is closed for all practical purposes. It is now taken as self-evident that the country's constitution and basic institutions cannot be amended, except at the margins. Merely evoking the possibility of such changes tends to be seen as futile, if not irresponsible.

\section{Assessing the Country's Constitutional Impasse}

Political scientists, philosophers and intellectuals have been preoccupied by this outcome, an unforeseen consequence of a long and broad debate to which, collectively, they have contributed with energy and conviction. If we abstract from the necessary nuances and minor points, four general interpretations can be distinguished: a lament for a simpler, less diverse, and less participatory past; a lament for a more reasonable, just as diverse but less participatory past; a celebration of democracy, from a majoritarian perspective; and a celebration of both democracy and multiplicity. Figure 1 presents these four interpretations along the two axes that define the authors' respective positions. The horizontal axis refers to the authors' more or less positive evaluations of democratization; the vertical axis to their views about social diversity, an aspect of the question that is related to democratization but distinct. ${ }^{2}$ Two authors are identified in each quadrant, as representative of the position thus defined.

${ }^{2}$ The term democratization is used here as defined by Dryzek. It refers not so much to the establishment of the basic institutional conditions for democracy, but rather to the process through which democracy progresses. "The democratic life," writes Dryzek, "consists in large part of searching for democracy." "(...) any worthwhile political future involves progressive democratization, not just in terms of the geographical spread of existing institutions widely thought to merit description as democratic, but also through a deepening of the democratic qualities of key arenas of life" (1996: 4-5). Michel Callon, Pierre Lascoumes and Yannick Barthe present in similar terms "the democratization of democracy" as a widely shared, broad and open aspiration that is inherent to democratic life (2001: 166 and 326). 
Figure 1: Four Assessments of Canada's Constitutional Impasse

Multiplicity/Recognition

\begin{tabular}{ll|ll} 
& & & \\
& & & \\
& Russell & Kymlicka & \\
Atkinson & Tully & Celebration/ \\
Elitism & Democratization \\
\cline { 2 - 4 } & Ajzenstat & Trudeau & \\
& Saul & &
\end{tabular}

Individualism/Integration

Consider, first, the lament for a simpler past. For political scientists like Janet Ajzenstat and Michael Lusztig, it was both the democratization of the constitutional process and the politics of recognition that led to an impasse. Ajzenstat links the two issues explicitly: "liberal democratic theory warns against popular participation in the process of drawing up a new constitution and, secondly, (...) the participation of political groups, interests, and individual Canadians in the negotiations is heightening contestation in the constitutional arena and hastening the country's breakup." (1994: 112). For her, the politics of recognition "has introduced a new and dangerously intolerant kind of divisiveness," and increasing participation will only make matters worse. Participation, in fact, offers a "remedy" that can only kill the "patient" (118). Michael Lusztig presents the same views with a different language. To ensure that democratization appears unsavory, Lusztig refers to it as "mass input/legitimization." This "mass" process, he argues, "undermines effective elite accommodation" and "is a 
catalyst for the creation of constitutional interest groups" that will just increase conflicts (1994: 748). Lusztig and Ajzenstat stand in a specific quadrant because they deplore not only public participation but also the expression of multiple identities and the multifaceted demands that characterize contemporary constitutional politics. To them, these demands cannot be differentiated on the basis of important principles; they merely reflect "the jockeying of organized groups and interests" (Ajzenstat, 1994: 120; and 2003: 140-43). Lusztig even refuses to see anything specific about the constitutional orientations of Quebec or of the Aboriginal peoples. The latter, in particular, are treated as one among many expressions of "minoritarianism," driven by the force of the "Aboriginal lobby" (1994: 753-54). In the end, all of these "constitutional rent-seekers" "each with an axe to grind" - have no strong claim, nothing more in any case than would have a hypothetical "collectivity of socially malcontent anarchist poets" (Lusztig, 1999: 469-70). Ajzenstat and Lusztig thus deplore the end of elite accommodation although one wonders what there is to accommodate in a country with no genuine diversity - and regret the loss of the "neutral constitution." Theirs is truly an elitist, majoritarian lament. Ajzenstat sees no solution now that that "Pandora's constitutional box is open," except a fragile status quo and a politics of "muddling through" that can best be preserved by "apathy" (Ajzenstat, 1994: 122 and 126; and 2003: 139). Lusztig, for his part, simply concludes that "the Dream of One Canada is over" (James and Lusztig, 2002: 101).

A second position expresses what could be called a lament for a more reasonable past. We find here the same worries about democratization but more openness, if not enthusiasm, about diversity and the need for recognition. Michael Atkinson, for instance, agrees with Ajzenstat and Lusztig about the association of democratic participation with "constitutional deadlock," but he diverges markedly from them in his assessment of the politics of recognition (1994: 745). Whereas the latter flatten all constitutional demands into interest group rent-seeking, Atkinson deplores precisely that the new political context fails to make room for "the idea that some groups have a prior claim on recognition because they derive their identity from a set of 
processes that have recognized them in the past" $(743){ }^{3}$ Likewise, Peter Russell, a distinguished representative of the "lament for a more reasonable past" view, considers that Canada can no longer deny "the new creed of popular sovereignty" and go back to elite accommodation, now that "the genie is clearly out of the bottle" (1993: 5-6). The problem, notes Russell, is that Canadians have not agreed, and probably cannot agree, to form a single people united by a social contract. The best hope for the country is to cling to what is left of its traditional understanding of diversity and consent. Canadians, concludes Russell, must realize that "they are after all the people of Edmund Burke, not John Locke, and that their social contract is essentially organic, not covenantal. Some of us might settle for that" (235).

A third standpoint can be defined as favorable to democratization but majoritarian in its understanding of diversity and recognition. Pierre Elliott Trudeau is the prominent representative here. Trudeau's rejection of a national status for Quebec and, at least initially, for Aboriginal peoples, and his commitment to an uncompromising liberal individualism are well known. ${ }^{4}$ Was he, however, favorable to democratization? In a sense, yes, but within the limits set by his opposition to existing national identities. First, one should recall that in his early writings Trudeau presented as a fundamental problem the lack of a strong democratic tradition in Canada:

Historically, French Canadians have not really believed in democracy for themselves; and English Canadians have not really wanted it for others. Such are the foundations upon which our two ethnic groups have absurdly pretended to be building democratic forms of government. No wonder the ensuing structure has turned out to be rather flimsy. (1968: 103)

${ }^{3}$ In his survey of the question, Matthew Mendelsohn (2000) places the three authors more or less in the same camp because he focuses on the horizontal dimension of Figure 1. These authors are, indeed, on the elitist side of the Figure, but their views of diversity and recognition (the vertical axis) are fundamentally at odds.

${ }^{4}$ A good synthesis is presented in Karmis and Gagnon (2001 : 150-61). 
Trudeau's constitutional program was meant, in part, to build a less "flimsy" structure, and to better anchor individual and linguistic rights in the constitution. There was a rhetorical and calculating dimension to the project of a "just society" centered on individual rights and defined by official bilingualism and multiculturalism, but the project was also a democratic one. At the same time, Trudeau was very much a political realist, always aware of the importance of power and manipulation. He made little efforts, for instance, to improve, or even to consider improving, existing practices regarding the financing of political parties, which he had denounced in his writings (Simpson, 1988; Whitaker, 1991). In power, he liked to refer to the people and sometimes evoked the possibility of a referendum, but in the end he always stuck to the traditional practices of executive federalism (Atkinson, 1994: 736; Buzzetti, 2003). Trudeau's appeal to an abstract Canadian people composed of undifferentiated rights-bearing individuals was in fact at the core of his political action, and it helps account for the tension between democratization and majoritarianism in his thought and actions. To undermine the idea of an old compact between nations at the origins of the federation, Trudeau conceived the Charter as establishing "the sovereignty of the people," a single people where "no one is special" (Trudeau, quoted in LaSelva, 1996: 90). Such a logic effectively pitted democratization against recognition and even, to a large extent, against federalism. At times, for instance, Trudeau simply overlooked the division of sovereignty inherent to federalism, to claim that the Members of Parliament were the only group in the country able to "express the national will and the national interest" (Trudeau, quoted in McRoberts, 2001: 702). In principle, this "national will" was taken as the will of a nation composed of minorities; effectively, it was the will of the majority (LaSelva, 1996: 89-98).

The same antinomies are found, in less sophisticated ways, in John Saul's essay on Canada, where the author claims that this country is "a nation of minorities" poorly governed by elites that have "lost contact with our reality" (1997: 10 and 127). Like Trudeau, Saul invents an abstract people that is not defined significantly by any national or linguistic cleavage ("we"), that is rarely well represented by its elites ("them"), and that happens to think ... just like John Saul ("us;" 1997: 222-23)! 
The democratization envisioned by Trudeau and Saul emphasizes what John Dryzek calls "franchise" and "scope," at the expense of "authenticity." It seeks to make the participation of the more vulnerable groups possible and easier (through multiculturalism policies and the Charter), and to expand "the domains of life under democratic control" (linguistic rights, for instance), but it fails to consider authenticity, "the degree to which democratic control is substantive rather than symbolic" (Dryzek, 1996: 5). This is why Trudeau and Saul need to invent an abstract people and to refrain from actual public consultations. Indeed, when taken seriously, the ideal of authenticity - a key component of the search for democratization - calls for the effective participation of various stakeholders and, in a multinational society, this leads unavoidably to the politics of recognition (Taylor, 1992: 28). ${ }^{5}$

In the last quadrant are authors who value both multiplicity and democratization. There are many variants here, and they will be discussed further below. Some authors - like Charles Taylor (1991), Jeremy Webber (1994: 312-19), Will Kymlicka (1998: 17583) and Charles Blattberg (2003a) - pay more attention to the politics of recognition and favor, in a rather abstract way, the pursuit of the country's "conversation." Others place more emphasis on democratization, and explore possible democratic avenues toward recognition (see, for instance, Mendelsohn, 2000; Tully, 2001; Maclure, 2003). The latter confront directly the question raised here, which has to do with the possibilities

${ }^{5}$ In Citizens Plus, Alan Cairns struggles with this antinomy and seeks to reconcile majoritarianism with some form of recognition for Aboriginal peoples (2000). Cairns still clings, however, to the majoritarian impulse, which he sees as essential and imperiled by Aboriginal self-government. In his insistence on the institutional difficulties associated with recognition, Cairns is also close to authors on the left side of the figure. Contrary to them, however, he celebrates the advent of broad citizen participation and the emergence of a "never-ending" constitutional dialogue. Yet, Cairns wishes a country defined by its unity of purpose and endowed with stable institutions (see Dobrowolsky and Devlin, 2002: 94-5 and 119). In many ways, and this is not a critique, Cairns stands close to the analytical and political crossroads, but in the end he remains on the majoritarian side. 
and potential of democratic deliberation in a multinational federation. But, as we will see, they also leave important questions unaddressed.

\section{Can Deliberation Be Achieved?}

Among the authors who value both democratization and the recognition of the country's diversity, one can find quite distinctive views about the possibility of achieving a workable democratic political order in a multinational federation. At the risk, once again, of oversimplifying, it is possible to distinguish four standpoints, according to the importance granted respectively to power and arguments, and to the relative optimism or pessimism of each author. Figure 2 presents, on the left side, authors who stress the arguments of power. Scholars in the lower quadrant see little possibilities for an opening, whereas those in the upper quadrant are just as sensitive to institutional and political constraints but see possibilities in institutional design. On the right side of the Figure are authors who place more emphasis on the power of arguments, and are either pessimistic or optimistic about the coming years in Canada. 


\title{
Figure 2: Four Assessments of Democratic Deliberation in a Multinational
} Federation

\author{
Optimistic
}

\begin{tabular}{l|ll} 
& $\begin{array}{l}\text { Resnick } \\
\text { Mendelsohn }\end{array}$ & $\begin{array}{l}\text { Webber } \\
\text { Tully }\end{array}$ \\
$\begin{array}{lll}\text { The Arguments } \\
\text { of Power }\end{array}$ & $\begin{array}{l}\text { McRoberts } \\
\text { Seymour }\end{array}$ & $\begin{array}{l}\text { Kymlicka } \\
\text { LaSelva }\end{array}$ \\
\cline { 2 - 3 } & Arguments
\end{tabular}

Pessimistic

Among scholars who insist on institutions and political power, most are pessimistic about the possibilities of reaching a satisfying accommodation in Canada. Kenneth McRoberts, for instance, presents the recent history of the country as a missed opportunity to adjust both institutions and practices to the reality of a multinational federation. From his point of view, it was not for lack of a good understanding of the challenges facing the federation that Canada was "misconceived," but rather because those who believed in a less diverse or pluralistic federation successfully used the majority's preferences as a lever to impose their favored solution (1997). The result, argues McRoberts, is an unstable construct that is at best an impasse and at worst doomed to fail (2001: 713). Michel Seymour pushes the argument further with a survey of recent federal policies aimed at undermining Quebec's national identity in favor of the 
new Canadian nationalism, policies that also include more authoritarian measures such as the Clarity Act (2001: 125-41). The federal government, argues Seymour, has negated both democratization and recognition, and there is no way out, unless Quebeckers opt for sovereignty. Because they value democratization and recognition, McRoberts and Seymour would agree with Dryzek that 'analgesia,' which they see as the dominant political position, is unsatisfying. They would not settle, however, for a restrictive politics of issue-specific deliberations, because such an approach would fail as well to address the country's core problems.

Authors like Philip Resnick and Matthew Mendelsohn are also sensitive to the role of institutions and power and they concur to a large extent with McRoberts' assessment. They place some hope, however, on political and institutional reforms that would make possible new, more democratic forms of accommodation. Resnick, for instance, considers other federations and proposes a new institutional arrangement that would distinguish provinces, region-provinces, and a nation-province, admitting in the same breath that for now there is not much appetite for such reforms in Canada (2000 and 2001). From a more specific perspective, Mendelsohn considers different deliberative ideas and experiments and suggests that there "may be more useful frameworks for thinking about constitutional change in Canada than traditional models of executive federalism and consociationalism." For him, new deliberative approaches could make it possible to include the public in the process "in a nonmajoritarian manner," thus opening an avenue for change (2000: 270-71). Like Resnick, Mendelsohn is fully aware that the path toward change is narrow: "the discourse of undifferentiated equality is deeply anchored and parties challenge this philosophy at their peril" (2002: 76). Still, he thinks that a coalition defending a more flexible, more accommodating federalism remains possible (2002: 76-77). In some ways, Mendelsohn's approach is not far from the pragmatic perspective advocated by Dryzek. It insists, however, on the unavoidable character of core constitutional issues, even though the prospects for change appear limited. 
The authors in the lower right quadrant are not far from Mendelsohn's position. Like him, and like all authors in Figure 2, they value deliberation and multiplicity. They would probably be more pessimistic, however, about the possibilities of institutional design, and be closer in this sense to McRoberts and Seymour, who stress difficulties more than possibilities. Contrary to the latter, however, they insist on pursuing the "Canadian conversation," even though they offer little reason to think that this conservation can be fruitful. Beyond their differences, Samuel LaSelva and Will Kymlicka both consider that the current impasse could be solved if Canadians were willing to make concessions. LaSelva concludes his book with the assertion that "the existence of Canada requires Canadians (...) to come to terms with asymmetrical federalism" (1996: 195). Kymlicka proposes, more prudently but in a similar manner, to "adopt a more flexible and open-minded approach" toward multiculturalism and national minorities (1998: 182-83). ${ }^{6}$ Ideas, here, come first. But the potential for deliberation appears unpromising, because the majority remains reluctant to accept the necessary approach. Citizens seem caught in a sort of 'agonistic' impasse.

Jeremy Webber offers a more compelling reason to pursue the "Canadian conversation" and, because of this, he leaves open more possibilities. The conversation must continue, he proposes, not because it leads to the one good solution, or even to some sort of working compromise, but simply because the conversation itself - "the way in which (the people of this country) have cooperated, disagreed, and in the end shaped each other" - is what constitutes Canada as a country (1994: 319). James Tully pushes this 'agonistic' intuition further, and argues that a stable and theoretically determined outcome simply can never be reached:

The language of constitutionalism and struggles for recognition disposes us to presume that there is some definitive and permanent system of rules of mutual recognition, some definitive configuration (...) on which all agree. (...) But this is false. '[l]nevitably, there will be dissenting voices.' What is definitive and

${ }^{6}$ Charles Taylor is also clear on this count, and concludes an analysis of the question with a plea for pluralism: "So let us recognize this now and take the road of deep diversity together" (1991). 
permanent is the democratic discussion and alteration of the rules over time. The members accept and respect this or that system of rules of recognition not because they agree on the system in virtue of some shared conception of justice, but because the rules are open to dissent, fair consideration and amendment. (Tully, 2001: 14-15)

In this perspective, the "continuous contests of mutual disclosure and acknowledgement" are "the activity of democratic freedom itself" (22), and citizens themselves must be the agents of change:

It is no longer assumed that the forms of recognition of members of a constitutional democracy can be determined outside the political process itself, by theoretical reason discovering the a priori forms of universal memberships (individuals, nations, corporations, provinces and so on). Also, it is no longer assumed that a consociational elite is capable of making the determination by some form of accommodation behind the back of citizens. It is now widely argued in theory and practice that the identities worthy of recognition must be worked out and decided on by the members of the association themselves, through the exercise of practical reason in negotiations and agreements. (Tully, 2001: 24)

By paying attention to dissent, conflicts and instability, Tully distances himself from the idea that a good theory can offer a satisfying answer to the politics of deliberation and recognition in a multinational federation, and he gives content to Webber's intuition about the critical and constitutive importance of the country's historical conversation, with all its limitations and disagreements. Tully nevertheless avoids the pitfalls of 'agonism' underlined by Dryzek, because he remains committed to "the exercise of practical reason in negotiations and agreements." His views, still, are bound to face a number of objections. Among these, it is worth considering two potential arguments. The first claims that such an open approach can only lead to instability and conflict, and would be rejected rapidly by a majority satisfied with the status quo. ${ }^{8}$ A second objection contends that an established state simply would not

${ }^{7}$ Tully quotes a sentence from the 1998 Supreme Court of Canada's Reference re Secession of Quebec.

${ }^{8}$ Kymlicka makes a similar point with reference to Webber and Taylor (1998: 176). Maclure also acknowledges the importance of this argument (2003: 16). 
allow such an open process of deliberation to develop, especially if national unity is at stake. ${ }^{9}$ Both objections raise the issue of power and send us back, in a sense, to the bottom left quadrant of Figure 2, where power is everything and deliberation almost nothing. In an opposite direction, one could claim that the process envisioned by Tully is simply too driven by conflicts and negotiations to make room for a genuine conversation (see Blattberg, 2003a and 2003b). This objection also sends us back to the bottom left quadrant, unless one can identify the political and institutional conditions necessary for a satisfyingly genuine conversation, a challenging demand in contemporary Canada.

These objections go well beyond Tully's approach, which is remarkably balanced in associating the requirements of deliberation with the reality of conflicts. They relate to the more general difficulty, in both political science and political philosophy, in thinking concurrently about democratic deliberation and political power. Predominantly, the study of politics has been a study of interests, institutions and force, focused on bargaining and power, with some attention being occasionally paid to ideas, considered as intervening variables. In recent years, the study of democratic deliberation has brought back a more traditional understanding of politics as a forum, where ideas and arguments are exchanged, evolve over time, and matter in their own right. It remains unclear, however, how exactly deliberation proceeds and matters in a context defined by interests, conflicts, and power.

This question is, of course, a theoretical one. But it also has important practical implications. The lack of a working conciliation of these two dimensions of politics may help to explain, for instance, the remarkable gap that exists between Canadian scholarship on federalism and the country's political life. There is a "total disjunction," observes McRoberts, between the leadership Canadian scholars have taken in theorizing multinational federalism and the evolution of the political realm in this country, which has denied this possibility, and effectively moved in the opposite direction (2001:

9 This argument underlies Seymour's critique of Tully's positive views on the Supreme Court of Canada's Reference re Secession of Quebec (Seymour, 2001: 147-60). 
694 and 710). Can we rebuild the connection, and think of democratic deliberation as a real, through and through, political activity?

\section{Democratic Deliberation as a Political Activity}

In political theory, democratic deliberation is usually contrasted with the interplay of interests and power, the two dynamics being seen as mutually exclusive (Dryzek, 2000: 2). In this perspective, arguing is successful precisely when it is sheltered from bargaining and domination. This separation can be achieved theoretically by assuming an ideal speech situation, which can then be used as a benchmark to assess concrete situations (see Chambers, 1996: 155-62), or else it can be sought through institutional design, with the introduction of procedures and approaches more conducive to deliberation (see Dryzek, 1990: 40-48). Most authors recognize that, in fact, arguing never takes place in a vacuum, away from interests, bargaining and power. They nevertheless tend to think about deliberation as happening in a distinct realm, or at a different moment, as far as possible from day-to-day politics. On the other side, of course, are authors who see only bargaining and power, and implicitly embrace the same dichotomy.

The question is posed very differently if, on the contrary, we start from the premise that deliberation and power politics are always closely intertwined and, in fact, impossible to separate. From this perspective, both processes, arguing and bargaining/dominating, take place in situations of conflict, when important ideas and interests are at stake. They evolve concurrently, and one cannot be understood fully without the other. Discourse itself is penetrated, and to some extent constituted, by power and resistance (Flyvbjerg, 2001: 93 and 116-28; Risse, 2000: 17-18). This does not mean that deliberations can be reduced to power relations, but it does imply that they cannot be understood out of their context, as somehow outside of power relations. Likewise, all power relations are legitimated by norms and arguments about justice, and it is a mistake to underestimate the political importance of such discourses (Risse, 2000: 17). The very decision to act unilaterally, to negotiate, or to deliberate is guided by 
norms and social and institutional rules, and unilateral and negotiated actions themselves are shaped by language and shared social understandings (Müller, 2004: 412-13).

Put differently, if principles were not at stake, bargaining and domination would hardly be political, and they would become more akin to trade or organized crime. If, on the other hand, interests, identities and power were set aside or ignored, deliberating would appear facile, and would be more an exercise in pure rhetoric than a genuinely political undertaking. The key analytical question, then, has to do with what could be called - in Keynesian terms - the weight of the arguments, the relative importance of ideas and power in a given case, at a specific moment (Risse, 2000: 18; Magnette, 2004; on this Keynesian notion, see Noël, 1995).

From this perspective, democratic deliberation can be seen as a normal "joint social activity, embedded in the social action of dialogue - the give and take of reasons" (Bohman, 1996: 32). Success does not require unanimity or even agreement, but simply that agents be "sufficiently convinced to continue their ongoing co-operation". The aim, write Callon, Lascoumes and Barthe, is not to find a consensus or the one best solution, but rather to reach a "robust" outcome, one that integrates various standpoints and preoccupations and allows the collective learning process to continue in a democratic way (2001: 16 and 55). Normally, this happens when the different sides can "recognize that they have contributed to and influenced the outcome, even when they disagree with it" (33). Disagreements remain - without them there would be no need for deliberation - but ideas and representations have evolved. To quote again from Bohman: "Each speaker incorporates and reinterprets the other's contributions in his or her own. After a sufficient length of time, speakers begin to use expressions that they did not employ before; the process of trying to convince others may alter not only one's own mode of expression but also the reasons one finds convincing" (58). Each participant's understanding of the common situation is reshaped as it incorporates other points of view and reasons. Deliberation generates "uptake." It remolds the different arguments through reciprocal influences. 
Deliberation may concern broad issues of rights, more specific policy issues, or even "unpretentious claims for decency" anchored in local notions of "honor and justice" (on the latter, see Sabel, 1982: xiii, 132, and 189). The general idea is the same: in a democracy, policies and practices cannot simply derive from earlier forms or emanate from unmediated power struggles. Changes must be justified with public reasons, which will always be contested but usually will be accepted as worth discussing, or at least acknowledged as legitimate (Bohman, 1996: 91 and 100; Risse, 2000; Stone, 2002: 34). This dialogic process shapes politics in many ways, just as the demands of politics shape public deliberations.

This understanding of public deliberation gives power to principles, because it grants contending conceptions of justice a genuine weight in the public arena, and it also anchors power relations into principles. From this perspective, the language of politics is at the same time a moral and democratic language and an institutional and technocratic discourse. This implies, among other things, that societies hardly ever go back. The notion of moral progress is rarely discussed by political scientists or by political theorists, but the fact that there has been historical progress in public ideas about justice is hard to dispute. Slavery or official racism, to take extreme but not so distant cases, are not likely to return as legitimate practices. Closer to the current context, recent workfare initiatives simply could not be justified with the same moral arguments put forward in the nineteenth century to support similar policies (King, 1999: 256). Like science, moral language can be seen as a genuine cognitive discourse, which advances over time (Sayre-McCord, 1986; Gilbert, 1990: 7-11 and 111-16).

Finally, democratic deliberation and power relations do not only forge public choices. They also create and transform social actors and their relationships, as well as public practices and institutions. In the give and take of arguments and of politics, new actors emerge, old ones are displaced or rejuvenated, and social arrangements are remade. The logic at play is not causal, but constitutive (Wendt, 1999: 77-88 and 135). 
The public "changes the conditions of political deliberation by changing itself" (Bohman, 1996: 201).

In the context of a multinational federation, the latter point is particularly important. It means that peoples and social actors change themselves as well as others through their interactions. If we also accept that arguments have weight, that there is "uptake" in the exchanges, and that there is moral progress over time, fears of an unruly and never-ending debate appear exaggerated. ${ }^{10}$ The constitutional representations of Canadian women, for instance, were not simply the narrow, divisive and endless claims of an "interest group." These representations defined new collective identities, contributed to open the political debate for all, and gave rise to new coalitions and compromises. In sum, they made the country not less but more inclusive, coherent and legitimate (Dobrowolsky, 1998: 740-41; and 2000: 197 and 201). Similarly, the recognition of Aboriginal peoples represents an historical step forward, which does call for further steps but cannot be questioned endlessly.

Like Tully's proposition, the approach outlined here suggests that there is no end to debates, no stable outcome that can be reached. A greater attention to power relations, however, also indicates that Tully may see more institutional and political flexibility than there is in reality in the Canadian context. In a specific social and political context, democratic deliberation always remains constrained. This means that some outcomes are more likely than others, whether they are just or not. Such constraints also imply, however, that social actors do not simply talk past each other, in an 'agonistic' way. Keen to promote an open democratic process, 'agonistic' proponents of deliberation have not always paid sufficient attention to the fact that the primary purpose of debating is to reach decisions on relatively stable rules. Jocelyn Maclure, for

${ }^{10}$ This preoccupation about unbounded debates is not unique to Canadian scholarship and concerns the politics of deliberation in general (see Dryzek, 2000: 31-56). Many students of multinational federalism have argued on empirical ground that the conversation should remain within reasonable boundaries (see Maclure, 2003: 16; Kymlicka, 1998: 182-83). 
instance, presents moments of decision as "tragic but unavoidable," as the dramas of political life (2000: 214). Of course, decisions make winners and losers, in normal as well as in constitutional politics, but what would be the point of fighting for, say, a law to combat poverty and social exclusion, if no durable and effective decision were ever made (on this case, see Noël, 2002). A constitution, observes Francis Delpérée in the Belgian context, should not be written on sand (2001).

Can we draw a line between democratic openness and the rigidity necessary to create rules and institutions that matter? Can a multinational federation like Canada, where the majority would prefer to close the constitutional debate, still engage in a fruitful deliberative process on issues of identity and recognition? Can we even speak of a single Canadian debate? Or do we already have, for all practical purposes, separate public spheres?

Philosophical and theoretical arguments cannot respond to these questions except to suggest that there is a middle way between 'analgesia' and 'agonism,' defined not by a narrowing of the range and scope of the issues under consideration but by a realist understanding of deliberation and of constitutional politics, as rule-bound debates defined by conflicts and by the possibility of accommodation more than by the elusive ideal of a rational and encompassing consensus (Bellamy and Schönlau, 2004: 417). In this perspective, only a close analysis of the political context can inform us about the difficulties and the possibilities of deliberation in this period, in one specific multinational federation (Risse, 2000: 18; Flyvbjerg, 2001: 135; Maclure, 2003). In the end, the best option is to trust the democratic process. Rogers M. Smith, who very aptly shows how the construction and expression of stories of peoplehood are inextricably linked to concrete power politics - and to democracy as well - argues in favor of such a realist politics of contestation, whereby various groups and nations can seek to define and institutionalize new communities and, in the process, more or less "check each other's excesses as they vie to win broad support in political contests" (2003: 156-60).

\section{Popular Consent in an Old Multinational Federation}


If democratic deliberation makes sense in a less than perfect context, and if Canadian politics is a public sphere where such deliberative practices take place, we should also be able to understand past developments from this perspective. It is not possible, within the constraints of a short article, to go very far in this direction. But consider, as an interesting illustration, the origins of the federation.

The men who designed the Canadian federation in 1867 were not exactly friends of democracy as we understand it today. "The weak point in democratic institutions"” said George-Étienne Cartier, "is the leaving of all power in the hands of the popular element. The history of the past proves this is an evil." In the same vein, Thomas D'Arcy McGee saw the new Confederation as a protection against "the risk of being swallowed up by the spirit of universal democracy that prevails in the United States" (Cartier and McGee, as quoted in Resnick, 1990: 76-77; see also Mendelsohn, 2000: 248-49). The Founding Fathers preferred a mixed constitution, with monarchical and aristocratic elements, and a limited franchise. At the same time, however, they displayed a keen sense of the requirements of popular consent in a multinational federation. Here is how John A. Macdonald, the country's first Prime Minister, explained the need for a federal arrangement in Canada:

I have always contented that if we could agree to have one government and one parliament, legislating for the whole of these peoples, it would be the best, the cheapest, the most vigorous, and the strongest system of government we could adopt. But, on looking at the subject in the [Quebec] Conference, and discussing the matter as we did, most unreservedly, we found that such a system was impracticable. In the first place, it would not meet the assent of the people of Lower Canada, because they felt that in their peculiar position - being a minority, with a different language, nationality and religion from the majority - in case of a junction with the other provinces, their institutions and their laws might be assailed, and their ancestral associations, on which they prided themselves, attacked and prejudiced; it was found that any proposition which involved the absorption of the individuality of Lower Canada - if I may use the expression would not be received with favour by her people. (Macdonald, in Waite, 1963: 4041). 
This discourse is well known and often quoted in Canada, but its implications for a discussion of democratic deliberation in a "really existing" multinational federation have not been considered with sufficient attention. Here is a key political leader who distrusts democracy and popular participation but seeks institutions that will meet the expectations and the favor of "the people of Lower Canada." One could argue that Macdonald was simply drawing conclusions from a bargaining process that had taken place among political elites, and making these conclusions legitimate by appealing to broader but relatively shallow principles. Such a narrow interpretation would not explain, however, the importance, for Macdonald, of referring to the "assent of the people of Lower Canada," and the weight he gave to political discussions carried "most unreservedly." Why was someone who did not support democracy paying so much attention to the views of others and to popular consent? Why did he see these arguments about discussion and consent as important and politically effective? How could he simultaneously oppose democracy and seek popular consent?

The key to understand Macdonald's views is contextual. Like most men of his time, Macdonald associated democracy with direct democracy, and contrasted it with a mixed constitution and representative government, which he saw as a more feasible and preferable mode of government (Resnick, 1990: 71-87). Representative government did not require universal suffrage - in time, the logic of a vote for all would impose itself or an equality of status between persons of different social classes, but it was strongly anchored in the principle of popular consent, according to which the governed could only have obligations toward a government that they had first accepted as legitimate (Manin, 1996: 11-13, 113-15, 126). Discussion also played a key role, not as a decision-making procedure but as a process that facilitated agreements and, in the end, made consent possible (Manin, 1996: 241-45). This is why Macdonald stressed that he and his peers had discussed the matter "most unreservedly" before coming to the conclusion that only a federal arrangement would obtain the "assent of the people of Lower Canada" (see also: Ajzenstat, 2003: 48-89). 
Whatever its reservations regarding popular participation, the theory of representative government was thus open to forms of deliberation, among the elites first but also with the people, at least indirectly. The theory, however, was not as sensitive to the implications of diversity. The republican tradition tended to see deliberation as a means to overcome differences, to find the general will or at least some joint understanding of the common good (Przeworski, 1991: 15; Ajzenstat, 2003: 78). More fundamentally, the dominant political theories of the time assumed that a modern constitution should be constructed de novo, by founding fathers willing and able to break with the traditions and irregularities of ancient constitutions, to create new nations of equals (Tully, 1995: 58-70). This understanding of modern constitutions was influential in Canada, and the country's "fathers" were tempted by the idea of creating a new nation (LaSelva, 1996: 25, 38 and 99). But they could not do so. Even the 1840 Union Act, which imposed a unitary government for Lower and Upper Canada, had failed to prevent the emergence of a strong and very elaborate scheme of political dualism. Unable to deny this tenacious social reality - which concerned a third of the population and was anchored in the country's ancient constitution (Tully, 1995: 145-46 and 154-62) Macdonald and his peers began to build what was perhaps the first modern federation designed to accommodate existing national differences (Burgess, 2001: 257).

A similar but more oppressive evolution took place with respect to Aboriginal peoples. Well before the creation of the modern Canadian federation, Aboriginal peoples had established a constitutional relationship with the state. They were indeed "alone among Canadian citizens in having entered treaties with the Crown" (Macklem, 2001: 136, 183 and 267). As Patrick Macklem underlines, this relationship was long denied and negated:

Throughout Canada's history, governments and courts systematically ignored the spirit and intent of treaties between Aboriginal peoples and the Crown, devalued ancient forms of Aboriginal sovereignty, dispossessed Aboriginal peoples of their ancestral territories, and regarded as inferior the diverse cultures to which Aboriginal peoples claim allegiance. (2001: 286-87)

The creation of Canada in 1867, for instance, was for the Aboriginal peoples "entirely an imperial imposition" (Russell, 1993: 32). Aboriginal peoples nevertheless 
maintained a minimal constitutional standing, which they claimed, and which was indirectly acknowledged by governments and courts when they argued that these claims had been extinguished or that consent was no longer necessary in this case (Tully, 1995: 138). In the 1970s and 1980s, the claims of Aboriginal peoples would reemerge and become, once again, central to Canada's constitutional debate.

For all its democratic limitations, the constitutional politics of the late nineteenth century followed a path that was neither 'analgesic' nor 'agonistic.' Anchored in the immediate preoccupations of politicians and informed by the need to find workable accommodations, the process nevertheless displayed a tension between the principled search for uniformity typical of modern constitutions and the equally principled demands for recognition and for the preservation of diversity that were anchored in the country's ancient constitution. This tension pitted the idea of a new nation against the protection of established ways of life, and confronted the elites of the new state with the complex requirements of popular consent in a multinational federation. The interplay of arguments, interests, and power relations was not what it is today, but it defined a new democracy and a new federation, which was built on a certain idea of continuity and consent and was conceived, at least indirectly, as multinational. ${ }^{11}$ The result proved lacking in many ways, but it was not a pure imposition or a strictly bargained outcome. Neither was it perfectly consensual nor cast in concrete forever. No sooner was it adopted that the meaning of the BNA Act of 1867 became challenged, contested and reconstructed in various ways by the different sides (Silver, 1997: 218-19 and 250).

${ }^{11}$ Michael Asch aptly described Canada as an "indirect" — or implicit — association of peoples (1984: 79). 


\section{Conclusion}

Like all deliberative processes of significance, the Canadian constitutional debate never was a nice and polite conversation, carried by well-meaning participants who had previously checked their interests and their advantages at the door. It often involved tough bargaining or verged on plain domination, was always less than perfectly democratic, and incorporated many restrictions and constraints that disadvantaged some or many constituents. This debate, however, was also anchored in principles about democracy, continuity, and consent, and it contributed to the establishment of important rights and relatively satisfying institutions and practices. This deliberative process was, in other words, a real political process. And it mattered very much.

The aim of this article was to consider the current Canadian constitutional impasse in light of the requirements and possibilities of democratic deliberation. The article first surveyed Canadian scholarship on the question, and found tensions, among those who favor democratization and pluralism, between an emphasis on the possibilities inherent to the Canadian debates and an acknowledgement of the difficulties of power relations in this country. It then proposed an understanding of deliberation that is not incompatible with the recognition of the role of interests and power in politics, and used the origins of the federation as an illustration.

Sensitive to the context and to both arguments and power relations, the approach outlined in this article cannot offer a theoretical or practical avenue out of the current Canadian constitutional impasse, nor can it provide a full-proof recipe for democratic deliberation in divided societies. Still, it could help us see beyond the dichotomies that tend to define the study of both Canadian politics and democratic deliberation.

In constitutional as in normal politics, some junctures and circumstances may be more favorable than others. These periods, however, need not be exceptional moments when principles can be considered dispassionately so as to achieve a consensus. Nor do they have to be prudently crafted and circumscribed exercises in cooperation, just a 
step ahead of 'analgesia.' Democratic deliberation over difficult issues of rights and recognition never stops. In one way or another, these issues permeate all political debates, and they continuously shape or engender rules and accommodations, albeit not always in a just, satisfying, or stable way. The possibility of democratic deliberation rests precisely on the citizens' capacity to develop principled arguments about these concerns, even in contexts strongly defined by power relations and not obviously favorable to deliberation.

For the moment, in Canada, there appears to be limited possibilities for meaningful progress. Debates, however, always go on, in one form or another. Canadians, for instance, are slowly coming to grasp with the requirements of aboriginal self-government, an issue easier to settle in principle than to define in concrete institutional terms (Cairns, 2000; Coates, 2000). Some also see progress in the September 2004 opening to the language of asymmetry in the federation. I have serious doubts in this case (Noël, 2004 and 2004-05). Whatever the case, no matter how constrained they are, in time, in one way or another, our debates and arguments tend to catch up with our political and social practices.

For more dramatically divided societies, the perspective outlined here implies that successful democratic deliberation may still be achieved, even in contexts where power and interests have much weight. Success, again, may depend less on limiting the franchise - or the range of involved participants - or the scope - the number and importance of issues to address - than on gambling on authenticity. The ensuing process may remain well below the demanding standards of normative democratic theory, but it has more chances to be effective in giving rise, gradually, to a genuine public sphere, where less than perfect but real, meaningful, and legitimate communication can develop. In Iraq, for instance, the new authorities have tackled directly the question of identity, to forge in April 2005 an elected government that is representative of the different components of a complex and very divided society. Of course, the road between this fragile and to some extent artificial consociational arrangement and the emergence of a true public sphere will be a long and difficult one. 
One should keep in mind, however, that even in the best conditions multinational deliberations always remain imperfect exercises in practical reason.

\section{Acknowledgements}

This article was completed while I was visiting professor at the PACTE/CERAT research centre of the Institut d'études politiques de Grenoble, in France. Earlier versions were presented at the April 2003 "Democratic Deliberation in Theory and Practice" conference organized in Montreal by the Centre de recherche en éthique de l'Université de Montréal, at the June 2003 Annual Meeting of the Canadian Political Science Association in Halifax, and, in November 2004, at the Institute for Canadian Studies of the University of Augsburg, Germany. I am grateful to the organizers and participants of these events for giving me the occasion to deliberate with them in an unconstrained and friendly context. For additional and very helpful written comments, I also thank Richard Bellamy, Charles Blattberg, Dominique Leydet, Jocelyn Maclure, Matthew Mendelsohn, Michel Seymour, James Tully, and this review's referees. 


\section{References}

Ajzenstat, Janet (1994). "Constitution Making and the Myth of the People," in Curtis Cook (ed.), Constitutional Predicament: Canada and the Referendum of 1992, Montreal and Kingston, McGill-Queen's University Press, pp. 112-26.

Ajzenstat, Janet (2003). The Once and Future Canadian Democracy: An Essay in Political Thought, Montreal and Kingston, McGill-Queen's University Press.

Asch, Michael (1984). Home and Native Land: Aboriginal Rights and the Canadian Constitution, Toronto, Methuen.

Atkinson, Michael M. (1994). "What Kind of Democracy Do Canadians Want?" Canadian Journal of Political Science, 27, 4, December, pp. 717-45.

Bellamy, Richard and Justus Schönlau (2004). "The Normality of Constitutional Politics: An Analysis of the Drafting of the EU Charter of Fundamental Rights," Constellations, 11, 3: 412-33.

Blattberg, Charles (2003a). Shall We Dance? A Patriotic Politics for Canada, Montreal and Kingston, McGill-Queen's University Press.

Blattberg, Charles (2003b). "Patriotic, Not Deliberative, Democracy," Critical Review of International Social and Political Philosophy, 6, 1, March: 155-74.

Bohman, James (1996). Public Deliberation: Pluralism, Complexity, and Democracy, Cambridge, MIT Press.

Burgess, Michael (2001). "Competing National Visions: Canada-Quebec Relations in a Comparative Perspective," in Alain-G. Gagnon and James Tully (ed.), Multinational Democracies, Cambridge, Cambridge University Press, pp. 25774.

Buzzetti, Hélène (2003). “Trudeau le réformiste: L'ex-premier ministre voulait permettre les référendums d'initiative populaire pour changer la Constitution," Le Devoir, May 2, p. A1.

Cairns, Alan C. (2000), Citizens Plus: Aboriginal Peoples and the Canadian State, Vancouver, UBC Press.

Callon, Michel, Pierre Lascoumes and Yannick Barthe (2001). Agir dans un monde incertain : essai sur la démocratie technique, Paris, Seuil. 
Chambers, Simone (1996). Reasonable Democracy : Jürgen Habermas and the Politics of Discourse, Ithaca, Cornell University Press.

Chambers, Simone (2003). "Deliberative Democratic Theory," Annual Review of Political Science, vol. 6: 307-26.

Coates, Ken (2000). The Marshall Decision and Native Rights, Montreal and Kingston, McGill-Queens University Press.

Delpérée, Francis (2001). "Belgique: la nouvelle vague fédéraliste," Revue française de droit constitutionnel, 48, October-December, pp. 675-86.

Dobrowolsky, Alexandra (1998). "Of 'Special Interest': Interest, Identity and Feminist Constitutional Activism in Canada," Canadian Journal of Political Science, 31 , 4, December, pp. 707-42.

Dobrowolsky, Alexandra (2000). The Politics of Pragmatism: Women, Representation and Constitutionalism in Canada, Toronto, Oxford University Press.

Dobrowolsky, Alexandra and Richard Devlin (2002). 'Citizens Supplicant?: Alan Cairns' Citizens Plus and the Politics of Aboriginal/Constitutional Scholarship," Review of Constitutional Studies, 7, 1 \& 2, pp. 79-119.

Dryzek, John S. (1990). Discursive Democracy: Politics, Policy, and Political Science, Cambridge, Cambridge University Press.

Dryzek, John S. (1996). Democracy in Capitalist Times: Ideals, Limits, and Struggles, Oxford, Oxford University Press.

Dryzek, John S. (2000). Deliberative Democracy and Beyond: Liberals, Critics, Contestations, Oxford, Oxford University Press.

Dryzek, John S. (2005). "Deliberative Democracy in Divided Societies: Alternatives to Agonism and Analgesia," Political Theory, vol. 33, no. 2, April: 218-42.

Dumont, Fernand (1993). Genèse de la société québécoise, Montréal, Boréal.

Flyvbjerg, Bent (2001). Making Social Science Matter: Why Social Inquiry Fails and How it can Succeed Again, Cambridge, Cambridge University Press.

Gilbert, Alan (1990). Democratic Individuality, Cambridge, Cambridge University Press. Heintzman, Ralph (1983). "The Political Culture of Quebec, 1840-1960," Canadian Journal of Political Science, 16, 1, March: 3-59. 
James, Patrick and Michael Lusztig (2002). "Say Goodbye to the Dream of One Canada: The Costly Failure to Purchase National Unity," in Hamish Telford and Harvey Lazar (eds.), Canada: The State of the Federation 2001; Canadian Political Culture(s) in Transition, Montreal and Kingston, McGill-Queen's University Press, pp. 83-109.

Karmis, Dimitrios and Alain-G. Gagnon (2001). "Federalism, Federation and Collective Identities in Canada and Belgium: Different Routes, Similar Fragmentation," in Gagnon and Tully (eds.), Multinational Democracies, pp. 137-75.

King, Desmond (1999). In the Name of Liberalism: Illiberal Social Policy in the United States and Britain, Oxford, Oxford University Press.

Kymlicka, Will (1998). Finding Our Way: Rethinking Ethnocultural Relations in Canada, Toronto, Oxford University Press.

LaSelva, Samuel (1996). The Moral Foundations of Canadian Federalism: Paradoxes, Achievements, and Tragedies of Nationhood, Montreal and Kingston, McGillQueen's University Press.

Levine, Marc V. (1997). La reconquête de Montréal, Montréal, vlb éditeur.

Lusztig, Michael (1994). "Constitutional Paralysis: Why Canadian Constitutional Initiatives Are Doomed to Fail," Canadian Journal of Political Science, 27, 4, December: 747-71.

Lusztig, Michael (1999). "Canada's Long Road to Nowhere: Why the Circle of Command Liberalism Cannot Be Squared," Canadian Journal of Political Science, 32, 3, September: 451-70.

Macklem, Patrick (2001). Indigenous Differences and the Constitution of Canada, Toronto, University of Toronto Press.

Maclure, Jocelyn (2000). Récits identitaires: le Québec à l'épreuve du pluralisme, Montréal, Québec/Amérique.

Maclure, Jocelyn (2003). "The Politics of Recognition at an Impasse? Identity Politics and Democratic Citizenship," Canadian Journal of Political Science, 36, 1, March: 3-21.

Maclure, Jocelyn and Alain-G. Gagnon (eds.) (2001). Repères en mutation: identité et citoyenneté dans le Québec contemporain, Montréal, Québec Amérique. 
Magnette, Paul (2004). "La convention européenne: argumenter et négocier dans une assemblée constituante multinationale," Revue française de science politique, 54, 1, February: 5-42.

Manin, Bernard (1996). Principes du gouvernement représentatif, Paris, Flammarion. McRoberts, Kenneth (1997). Misconceiving Canada: The Struggle for National Unity, Toronto, Oxford University Press.

McRoberts, Kenneth (2001). "Canada and the Multinational State," Canadian Journal of Political Science, 34, 4, December: 683-713.

Mendelsohn, Matthew (2000). "Public Brokerage: Constitutional Reform, Public Participation, and the Accommodation of Mass Publics," Canadian Journal of Political Science, 33, 2, June: 245-73.

Mendelsohn, Matthew (2002). "Four Dimensions of Political Culture in Canada Outside Quebec: The Changing Nature of Brokerage and the Definition of the Canadian Nation," in Telford and Lazar (eds.), Canada: The State of the Federation 2001, pp. 51-82.

Müller, Harald (2004). "Arguing, Bargaining and All That: Communicative Action, Rationalist Theory and the Logic of Appropriateness in International Relations," European Journal of International Relations, 10, 3: 395-435.

Noël, Alain (1993). "Politics in a High Unemployment Society," in Alain-G. Gagnon (ed.), Quebec: State and Society, Second edition, Toronto, Nelson Canada, pp. 422-49.

Noël, Alain (1994). "Deliberating a Constitution: The Meaning of the Canadian Referendum of 1992," in Cook (ed.), Constitutional Predicament, pp. 64-81.

Noël, Alain (1995). "Délibération démocratique et innovations politiques," Cahiers de recherche sociologique, 24: 127-60.

Noël, Alain (2000). "General Study of the Framework Agreement," in Alain G. Gagnon and Hugh Segal (eds.), The Canadian Social Union Without Quebec: Eight Critical Analyses, Montreal, Institute for Research on Public Policy, pp. 9-35.

Noël, Alain (2002). "A Law Against Poverty: Quebec's New Approach to Combating Poverty and Social Exclusion," Background Paper - Family Network, Ottawa, Canadian Policy Research Networks, December (www.cprn.org). 
Noël, Alain (2003a). "Power and Purpose in Intergovernmental Relations," in Sarah Fortin, Alain Noël and France St-Hilaire (eds.), Forging a Canadian Social Union: SUFA and Beyond, Montreal and Kingston, McGill-Queen's University Press, 2003, pp. 47-68.

Noël, Alain (2003b). "Construire la souveraineté par la base," in Yvon Leclerc and Claude Béland (eds.), La voie citoyenne: pour renouveler le modèle québécois, Montréal, Plurimédia, pp. 255-73.

Noël, Alain (2004). "Ici et ailleurs: déblocages?," Policy Options, 25, 10, November: 48.

Noël, Alain (2004-05). "Ici et ailleurs: de la formule à l'enveloppe," Policy Options, 26, 1, December-January: 67-68.

Przeworski, Adam (1991). Democracy and the Market: Political and Economic Reforms in Eastern Europe and Latin America, Cambridge, Cambridge University Press.

Resnick, Philip (1990). The Masks of Proteus: Canadian Reflections on the State, Montreal and Kingston, McGill-Queen's University Press.

Resnick, Philip (2000). The Politics of Resentment: British Columbia Regionalism and Canadian Unity, Vancouver and Montreal, University of British Columbia Press and Institute for Research on Public Policy.

Resnick, Philip (2001). "Repenser le fédéralisme canadien: provinces, régionsprovinces et nation-province," in Maclure and Gagnon (eds.), Repères en mutation, pp. 377-91.

Risse, Thomas (2000). "'Let's Argue!': Communicative Action in World Politics," International Organization, 54, 1, Winter: 1-39.

Russell, Peter H. (1993). Constitutional Odyssey: Can Canadians Become a Sovereign People?, Second Edition, Toronto, University of Toronto Press.

Sabel, Charles F. (1982). Work and Politics: The Division of Labor in Industry, Cambridge, Cambridge University Press.

Saul, John (1997). Reflections of a Siamese Twin: Canada at the End of the Twentieth Century, Toronto, Penguin Books.

Sayre-McCord, Geoffrey (1986). "The Many Moral Realisms," Southern Journal of Philosophy, 24, Supplement: 1-22. 
Seymour, Michel (2001). Le pari de la démesure: l'intransigeance canadienne face au Québec, Montréal, L'Hexagone.

Silver, Arthur I. (1997). The French-Canadian Idea of Confederation, Second Edition, Toronto, University of Toronto Press.

Simeon, Richard and lan Robinson (1990). State, Society, and the Development of Canadian Federalism, Volume 71 of the Studies for the Royal Commission on the Economic Union and Development Prospects for Canada, Toronto, University of Toronto Press.

Simpson, Jeffrey (1988). Spoils of Power: The Politics of Patronage, Don Mills (Ont.), Collins.

Smith, Rogers M. (2003). Stories of Peoplehood: The Politics and Morals of Political Membership, Cambridge, Cambridge University Press.

Stone, Deborah (2002). Policy Paradox: The Art of Political Decision Making, Revised edition, New York, W. W. Norton.

Taylor, Charles (1991). "Shared and Divergent Values," in Ronald Watts and Douglas Brown (eds.), Options for a New Canada, Toronto, University of Toronto Press, pp. 53-76.

Taylor, Charles (1992). "The Politics of Recognition," in Amy Gutman (ed.), Multiculturalism and 'The Politics of Recognition,' Princeton, Princeton University Press, pp. 25-73.

Tilly, Charles (1998). Durable Inequality, Berkeley, University of California Press.

Trudeau, Pierre Elliott (1968). Federalism and the French Canadians, Toronto, Macmillan.

Tully, James (1995). Strange Multiplicity: Constitutionalism in an Age of Diversity, Cambridge, Cambridge University Press.

Tully, James (2001). "Introduction," in Gagnon and Tully (eds.), Multinational Democracies, pp. 1-33.

Waite, P. B. (ed.) (1963). The Confederation Debates in the Province of Canada/1865, Toronto, McClelland and Stewart. 
Webber, Jeremy (1994). Reimagining Canada: Language, Culture, Community, and the Canadian Constitution, Montreal and Kingston, McGill-Queen's University Press.

Wendt, Alexander (1999). Social Theory of International Politics, Cambridge, Cambridge University Press.

Whitaker, Reg (1991). A Sovereign Idea: Essays on Canada as a Democratic Community, Montreal and Kingston, McGill-Queen's University Press. 